\title{
Quinacrine accumulation in pancreatic islet cells of rat and mouse: relationship to functional activity and effects on basal and stimulated insulin secretion
}

\author{
I. Lundquist ${ }^{1}$, B. Ahrén ${ }^{1}$, R. Håkanson ${ }^{1}$ and F. Sundler ${ }^{2}$ \\ Departments of ${ }^{1}$ Pharmacology and ${ }^{2}$ Histology, University of Lund, Lund, Sweden
}

\begin{abstract}
Summary. The fluorescent acridine derivative, quinacrine, was found to accumulate in rat and mouse pancreatic islet cells storing insulin, glucagon, pancreatic polypeptide, or somatostatin. Following administration of large doses of tolbutamide via an oro-gastric tube, the intensity of quinacrine fluorescence of insulin cells was substantially reduced. Similarly, the pancreatic insulin content was lowered. In contrast, the fluorescence intensity of the glucagon, pancreatic polypeptide and somatostatin cells appeared unaffected. Basal plasma insulin levels in the mouse were slightly elevated following quinacrine administration (25\%). Glucose-stimulated
\end{abstract}

insulin release was markedly enhanced (51\%) in quinacrinepretreated animals, whereas insulin release induced by cholinergic stimulation was unaffected. The results show that quinacrine accumulates in the various pancreatic islet cells. The drug seems to be confined to the secretory granules and affects the insulin response to glucose but not that to cholinergic stimulation, suggesting that these secretagogues act through different or partly different secretory pathways.

Key words: Pancreatic islets, quinacrine accumulation, tolbutamide, pancreatic insulin, plasma insulin, glucose, carbachol.
The fluorescent anti-malarial acridine derivative, quinacrine, was recently found to accumulate in pancreatic islet cells $[1,2]$ with an apparent half-life of about $40 \mathrm{~h}$ in the insulin cells [2]. Fluorescence microscopic examination indicated that the fluorophore accumulated in the secretory granules and it was suggested that the disappearance rate of the fluorescence might reflect the turnover of granules and thus the secretory activity of the cell [2].

The aims of the present investigation were (1) to establish which of the pancreatic endocrine cell types accumulated quinacrine, (2) to elucidate whether quinacrine accumulation in the insulin cells was affected by their secretory activity, and (3) to examine the effect of quinacrine on stimulated insulin release.

\section{Materials and methods}

\begin{abstract}
Animals
Female mice of the NMRI strain (weight $25-35 \mathrm{~g}$ ) and female Wistar rats (weight $150-200 \mathrm{~g}$ ) were used. Animals had free access to food (standard pellet diet; Astra-Ewos, Södertälje, Sweden) and water.
\end{abstract}

\section{Drugs and chemicals}

Quinacrine hydrochloride was obtained from Serva, Heidelberg, FRG. Gum tragacanth was from Sigma Chemicals, St. Louis, Missou- ri, USA. Tolbutamide was from Hoechst, Frankfurt/Main, FRG. All other chemicals were from British Drug Houses, Poole, Dorset, UK.

\section{Fluorescence microscopy and immunocytochemistry}

Small tissue specimens were taken from the splenic and duodenal parts of the pancreas ( $24 \mathrm{~h}$ after the intraperitoneal injection of quinacrine; $19.6 \mu \mathrm{mol} / \mathrm{kg}$ ) and frozen in a propane-propylene mixture at the temperature of liquid nitrogen. After freeze-drying and fixing by exposure to formaldehyde gas at $80^{\circ} \mathrm{C}$ for $1 \mathrm{~h}$, the specimens were embedded in paraffin or Epon (Polaron, Watford, Herts, UK). Paraffin sections $(6 \mu \mathrm{m}$ in thickness), were mounted in Entellan (Merck, Darmstadt, FRG) and examined by fluorescence microscopy using filters giving excitation at $405 \mathrm{~nm}$ (Leitz, Wetzlar, FRG). Occasionally sections were stained with aldehyde fuchsin which is reported to demonstrate insulin storing granules [3].

For identification of quinacrine-containing cells, consecutive plastic sections $(1 \mu \mathrm{m})$ were examined, one for quinacrine fluorescence and the other for the presence of insulin [4], glucagon [5], pancreatic polypeptide [6], or somatostatin [7] using immunocytochemistry [4-7]. Details of the hormone antisera are given in Table 1. Immunoperoxidase (PAP) staining was used throughout.

For measurement of fluorescence intensities the exciting wavelength of $405 \mathrm{~nm}$ was obtained from a stabilized DC $\mathrm{Hg}$ lamp (HBO $200 \mathrm{~W} / 2$, Osram, Stockholm, Sweden) and the emission monochromator (Zeiss, Oberkochen, FRG) was set to transmit the wave-length of maximum emission. Relative fluorescence intensities were determined by measuring the photocell output with a precision galvanometer. Extra-insular parts of the pancreatic parenchyma were used to obtain blank values. Each value is the mean of five to six recordings from each paraffin section. Correlation between fluorometer readings and amounts of quinacrine in islet cells has not been possible and the method has to be regarded as semi-quantitative. The instrument used has been described previously [8]. For further details of the procedure see Ekelund et al. [2]. 
Table 1. Details of the antisera used

\begin{tabular}{|c|c|c|c|c|c|}
\hline Antigen & $\begin{array}{l}\text { Immunization } \\
\text { in }\end{array}$ & Code no. & $\begin{array}{l}\text { Working dilution } \\
\text { immunofluorescence } \\
\text { staining }\end{array}$ & Source & References \\
\hline Bovine insulin & Guinea-pig & LA1 & $1: 80(3 \mathrm{~h})$ & L. Heding, Novo, Bagsvaerd, Denmark & 4 \\
\hline Porcine glucagon & $\begin{array}{l}\text { Rabbit } \\
\text { Rabbit }\end{array}$ & $\begin{array}{l}7811 \\
4304\end{array}$ & $\begin{array}{l}1: 1280 \\
1: 80(3 \mathrm{~h})\end{array}$ & $\begin{array}{l}\text { Milab, Malmö, Sweden } \\
\text { J. Holst, Copenhagen, Denmark }\end{array}$ & $\overline{5}$ \\
\hline $\begin{array}{l}\text { Bovine pancreatic } \\
\text { polypeptide }\end{array}$ & Rabbit & BPP & $1: 320$ & R. E. Chance, Eli Lilly, Indiana, USA & 6 \\
\hline $\begin{array}{l}\text { Somatostatin } \\
\text { (protein-conjugated) }\end{array}$ & $\begin{array}{l}\text { Rabbit } \\
\text { Rabbit }\end{array}$ & $\begin{array}{l}\text { K } 18 \\
19578\end{array}$ & $\begin{array}{l}1: 200 \\
1: 480\end{array}$ & $\begin{array}{l}\text { Milab, Malmö, Sweden } \\
\text { M. P.Dubois, Nouzilly, France }\end{array}$ & $\overline{7}$ \\
\hline
\end{tabular}
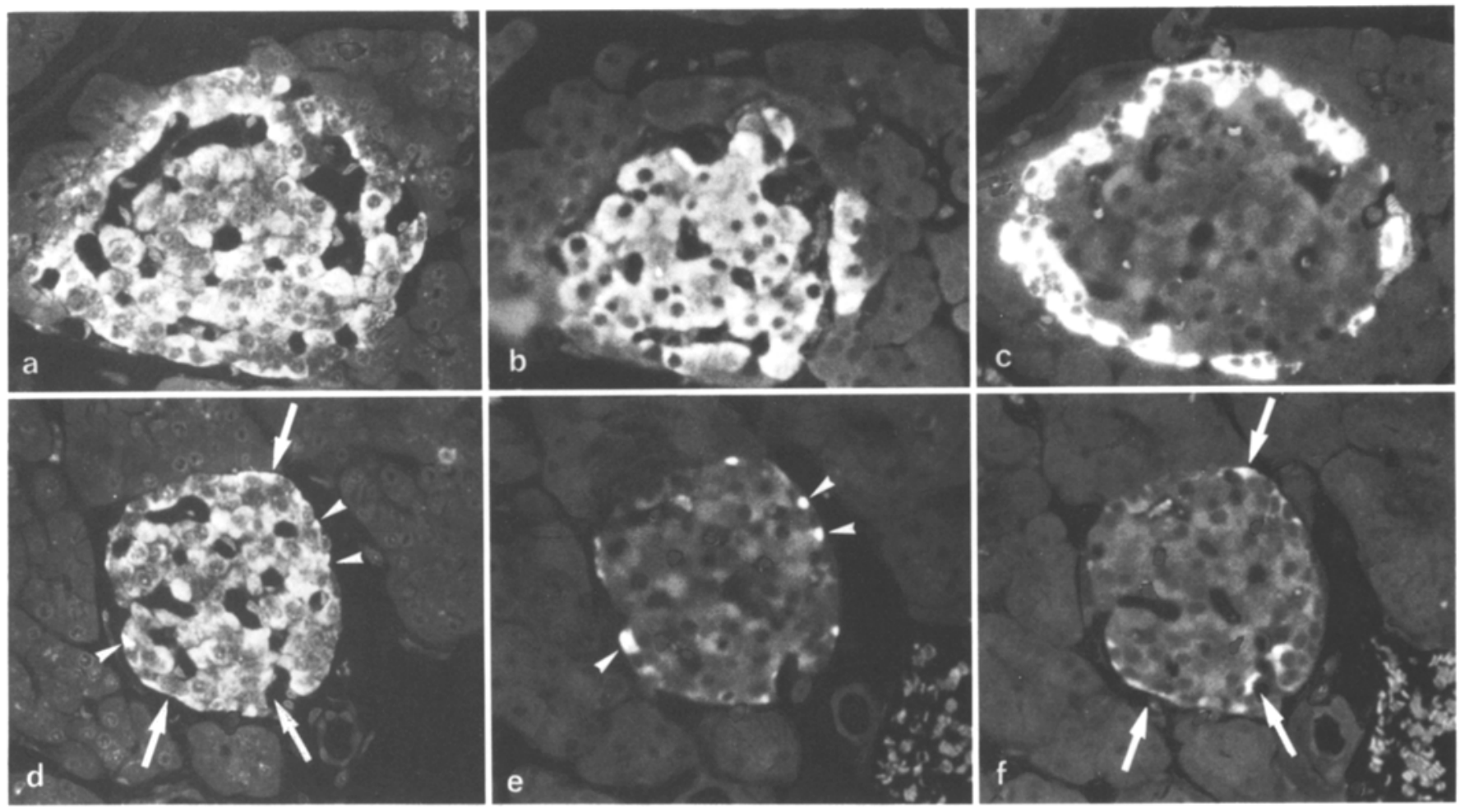

Fig. 1a-f. Correlation of quinacrine-fluorescent islet cells in rat pancreas with immunostained cells in two series of three consecutive plastic sections $(1 \mu \mathrm{m})$. a Quinacrine fluorescence, $\mathbf{b}$ insulin immunofluorescence, $\mathbf{c}$ glucagon immunofluorescence, $\mathbf{d}$ quinacrine fluorescence, $\mathbf{e}$ pancreatic polypeptide immunofluorescence, $\mathbf{f}$ somatostatin immunofluorescence. Arrows indicate localization of somatostatin cells with quinacrine fluorescence, arrow heads indicate pancreatic polypeptide cells $(\times 188)$

\section{Experimental procedure}

Quinacrine $(19.6 \mu \mathrm{mol} / \mathrm{kg})$, dissolved in $\mathrm{NaCl}(0.154 \mathrm{~mol} / 1)$, was given intraperitoneally $20 \mathrm{~h}$ before intravenous injection of approximately half-maximal doses of glucose $(2.8 \mathrm{mmol} / \mathrm{kg})$ or carbachol $(0.16 \mu \mathrm{mol} / \mathrm{kg})$. The compounds were dissolved in $\mathrm{NaCl}(0.154 \mathrm{~mol} / 1)$ and given in a tail vein at a volume of $0.2 \mathrm{ml} / 20 \mathrm{~g}$. Blood was sampled by the orbital bleeding technique in conscious mice as described previously [8]. Plasma immunoreactive insulin levels were recorded $2 \mathrm{~min}$ after injection of the secretagogues. Repeated experiments in this laboratory have shown that maximum concentrations of immunoreactive insulin in mouse plasma following a rapid intravenous injection of these compounds are reached after approximately 2 min [10]. Pancreatic insulin was extracted in acid ethanol as described previously [11].

In one series of experiments mice or rats were given tolbutamide $(1.8 \mathrm{mmol} / \mathrm{kg})$ suspended in $0.5 \%(\mathrm{wt} / \mathrm{vol})$ tragacanth solution through an oro-gastric tube. Control animals received only the vehicle. In mice this dose of tolbutamide was administered three times according to the following protocol: day 1 in the afternoon; day 2 in the morning and in the afternoon. Quinacrine was injected on day 2 in the afternoon $1 \mathrm{~h}$ after the last tolbutamide administration and the pancreas was excised $20 \mathrm{~h}$ later (i.e. on day 3 ). The rats were given the same dose of tolbutamide on day 1 in the afternoon and on day 2 in the morning (i.e. only twice). Otherwise the same protocol was used. The volume load was $1 \mathrm{ml}$ for the mice and $2 \mathrm{ml}$ for the rats.

\section{Insulin and glucose determinations}

The concentrations of insulin in plasma and pancreas were determined by radioimmunoassay [12]. Appropriate mouse or rat insulin standards (Novo Research Institute, Bagsvaerd, Denmark) were used. Plasma glucose levels were determined enzymatically [13]. 

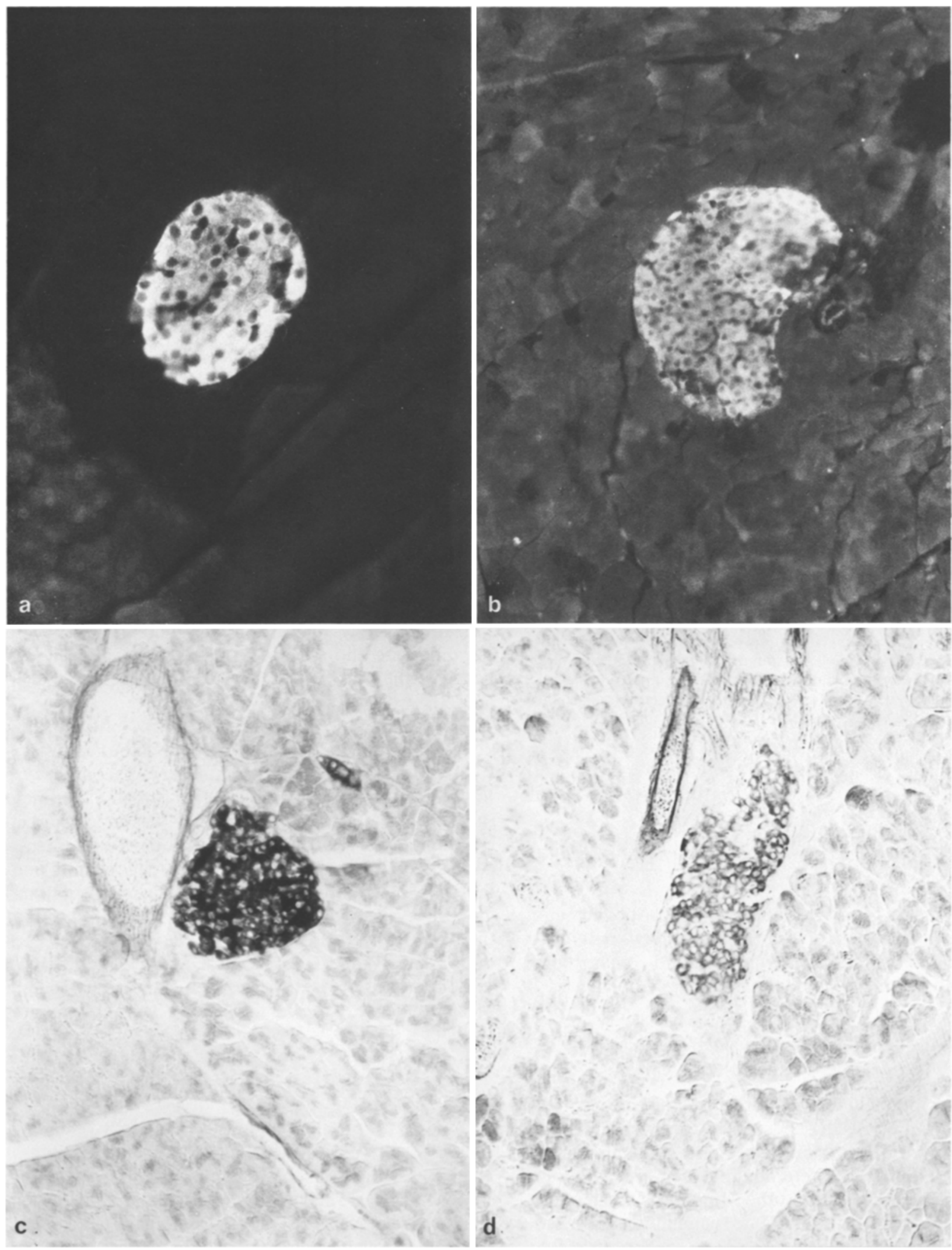

Fig. 2a-d. Insulin immunofluorescense $(\mathbf{a}, \mathbf{b})$ is not overtly affected by tolbutamide, whereas aldehyde fuchsin staining (c, $\mathbf{d})$ is greatly reduced. Paraffin sections. a, $\mathbf{c}$ Control mouse; $\mathbf{b}, \mathbf{d}$ tolbutamide-treated mouse $(\times 250)$ 

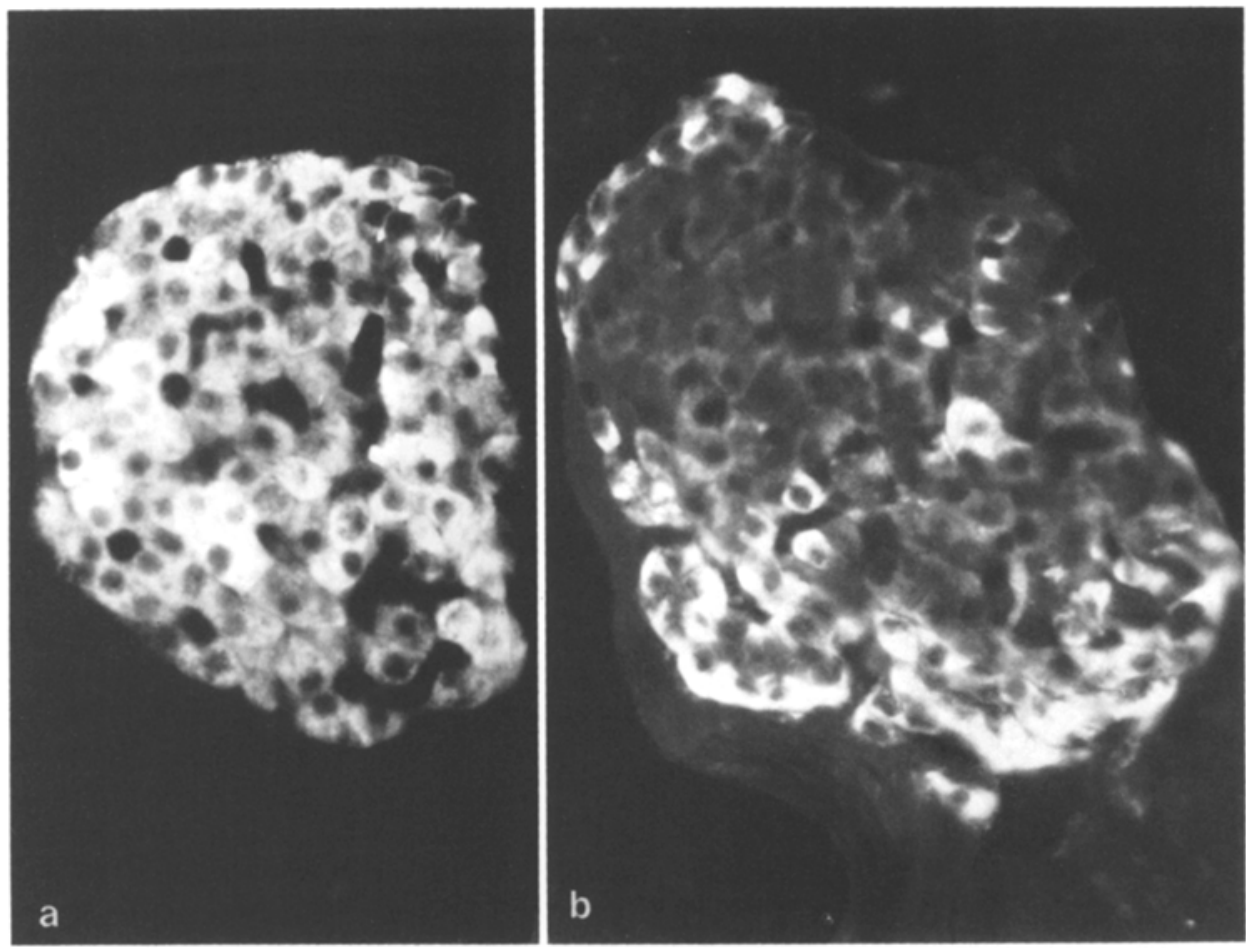

Fig. 3a and b. Quinacrine fluorescence in insulin cells is reduced by tolbutamide. a control mouse; $\mathbf{b}$ tolbutamide-treated mouse. Paraffin sections. Note that cells in the peripheral parts of the islet appear unaffected $(\times 350)$

\section{Statistical analysis}

Student's t-test was empolyed for tests of significance. Mean \pm SEM are given. Increase $(\Delta)$ in plasma immunoreactive insulin concentrations in response to stimulation was calculated by subtracting the basal plasma insulin concentrations in appropriate control groups, and by calculating the weighted SEM, taking into account SEM of both groups.

\section{Results}

\section{Distribution of quinacrine amongst islet endocrine cell types}

Quinacrine was found to bind avidly to most pancreatic islet cells in the mouse and rat. Figure 1 shows that insulin, glucagon, pancreatic polypeptide and somatostatin cells can accumulate quinacrine in their cytoplasm.

\section{Effects of tolbutamide pretreatment on quinacrine distribution among islet endocrine cells}

In an attempt to elucidate whether quinacrine accumulation in insulin cells depends on the presence of insulin secretory granules and/or the presence of insulin, large doses of tolbutamide were administered repeatedly to mice via an oro-gastric tube. Immunocytochemical staining for insulin revealed a seemingly unaffected immunofluorescence intensity in the insulin cells following tolbutamide (Fig.2). The unchanged insulin immunostaining after tolbutamide probably reflects the limitations of the immunocytochemical procedure as a technique for quantitative studies. In contrast, they stained only very weakly with aldehyde-fuchsin indicat- ing an almost complete loss of stainable granular material. Interestingly, the insulin cells were almost devoid of quinacrine fluorescence, whereas quinacrine fluorescence of the other islet cell types appeared unaffected (Fig. 3).

The quinacrine fluorescence intensity of the insulin cells was reduced by about $55 \%$ in tolbutamide-pretreated mice, and the pancreatic insulin content was lowered by about $40 \%$ (Fig. 4 a). In a similar experiment in the rat, the effect of tolbutamide was more marked than in the mouse. The quinacrine fluorescence intensity was reduced by $75 \%$ and the pancreatic insulin content was lowered by $65 \%$ (Fig. 4b). Plasma insulin and glucose levels in these animals at the time of removal of the pancreas were as follows; plasma insulin, $15.7 \pm 2.4$ and $29.6 \pm 4.4 \mathrm{mU} / 1$ for control $(n=7)$ and tolbutamide-treated $(n=7)$ rats, respectively $(p<0.02)$, and plasma glucose, $5.5 \pm 0.2$ and $4.6 \pm 0.3 \mathrm{mmol} / 1$, respectively $(p<0.05)$.

\section{Effect of quinacrine on basal and stimulated insulin secretion}

The effect of quinacrine on basal levels of insulin and glucose in mouse plasma $20 \mathrm{~h}$ after its administration is shown in Figure 5a. Quinacrine raised the basal plasma insulin levels by $25 \%$. This slight increase was not accompanied by any change in plasma glucose levels.

In the next series of experiments, the effects of quinacrine pretreatment on stimulated insulin release were studied. A half-maximal dose of glucose or the cholinergic agonist carbachol was injected intravenously and the acute insulin release recorded. Glucose-stimulated 

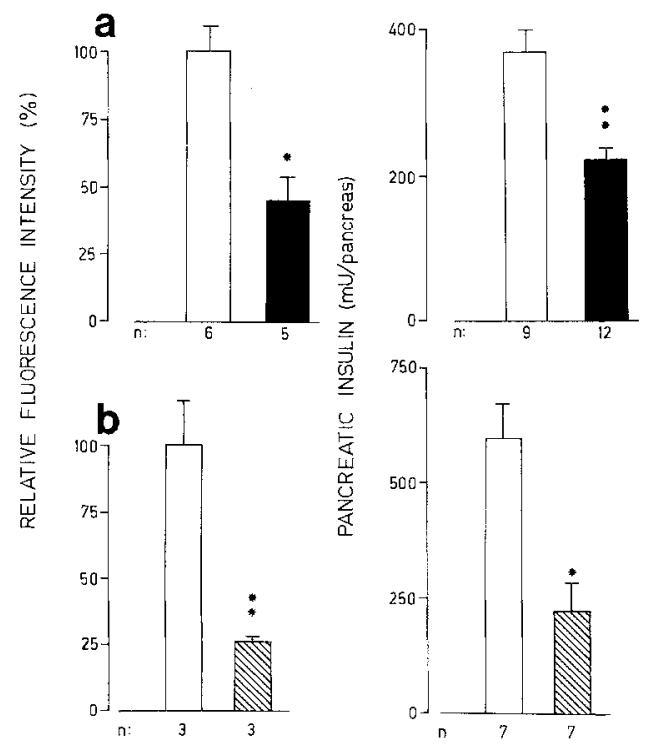

Fig.4. a Relative fluorescence intensity of quinacrine in islet insulin cells (left panel), and pancreatic insulin content (right panel) at $20 \mathrm{~h}$ after injection of quinacrine $(19.6 \mu \mathrm{mol} / \mathrm{kg})$ to mice given either vehicle $\square$ or tolbutamide $\boldsymbol{\nabla}(1.8 \mathrm{mmol} / \mathrm{kg})$ via on oro-gastric tube at $24 \mathrm{~h}$, $7 \mathrm{~h}$ and $1 \mathrm{~h}$ before quinacrine administration. b Relative fluorescence intensity of quinacrine in islet insulin cells (left panel), and pancreatic insulin content (right panel) at $20 \mathrm{~h}$ after injection of quinacrine $(19.6 \mu \mathrm{mol} / \mathrm{kg})$ to rats given either vehicle $(\square)$ or tolbutamide $(\$)$ $(1.8 \mathrm{mmol} / \mathrm{kg})$ via an oro-gastric tube at $24 \mathrm{~h}$ and $7 \mathrm{~h}$ before quinacrine administration. $n=$ number of animals examined. $* p<0.01$, $* * p<0.001$

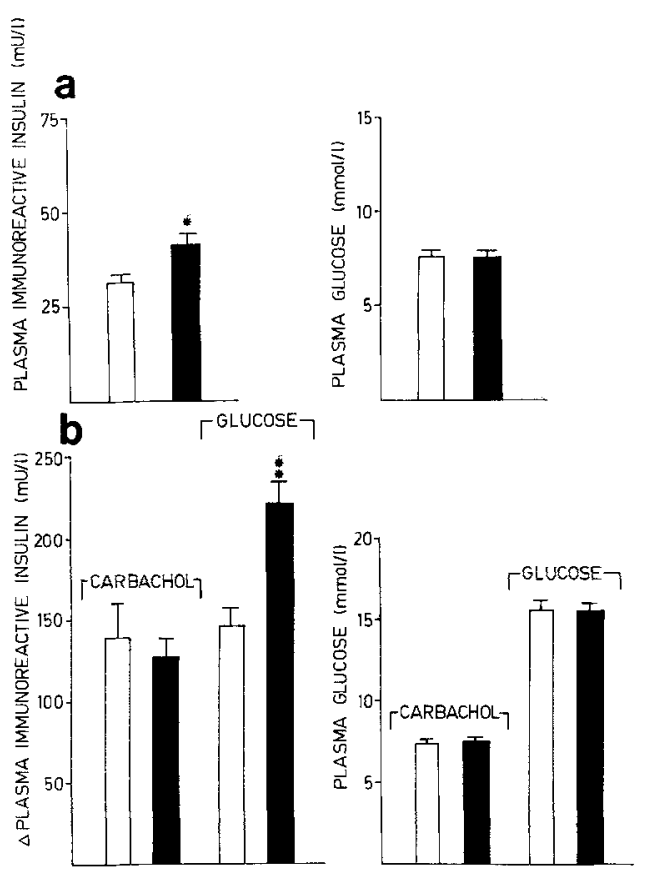

Fig. 5. a Basal levels of immunoreactive insulin and glucose in mouse plasma $20 \mathrm{~h}$ after injection of quinacrine $(19.6 \mu \mathrm{mol} / \mathrm{kg}, \mathbf{a})$ or saline ( $\square)$. b Increase $(\Delta)$ in plasma levels of immunoreactive insulin $2 \mathrm{~min}$ after an intravenous injection of approximately half-maximal doses of carbachol $(0.16 \mu \mathrm{mol} / \mathrm{kg})$ or glucose $(2.8 \mathrm{mmol} / \mathrm{kg})$ in mice pretreated with quinacrine $(19.6 \mu \mathrm{mol} / \mathrm{kg}, \mathbf{0})$ or saline (control, $\square$ ) at $20 \mathrm{~h} \mathrm{be}$ fore the experiment. Plasma glucose levels are shown in the right panel. There were 16 animals in each group. ${ }^{*} p<0.01,{ }^{* *} p<0.001$ insulin release was markedly enhanced in quinacrine pretreated animals, whereas insulin release induced by carbachol was unaffected (Fig. 5b). No difference was observed between controls and quinacrine pretreated animals with regard to plasma glucose levels.

\section{Discussion}

Recent investigations have shown that the fluorescent acridine derivative, quinacrine, accumulates in several peptide hormone-producing cell systems, including the pancreatic islet cells $[1,2]$. Similarly, the quinacrine analogue, chloroquine, has been observed to display a high uptake in pancreatic islets both in vivo and in vitro [14-16]. However, previous work did not establish whether all the major islet cell types, i.e. insulin-, glucagon-, somatostatin- and pancreatic polypeptide-containing cells, had the ability to accumulate and store quinacrine and its analogues. The results of the present study suggest that they do. One possible mode of accumulation of quinacrine in tissues is trapping through protonation within intracellular organelles of low $\mathrm{pH}$ such as secretory granules and lysosomes [17-19].

The data from the experiments with tolbutamide lend support to the assumption [2] that a major proportion of the accumulated quinacrine in the insulin cells is associated with the secretory granules. Tolbutamide treatment reduced the insulin content and virtually eliminated aldehyde-fuchsin stainable material, the nature of which is unknown. After tolbutamide-treatment, insulin cells were less efficient in accumulating quinacrine, whereas the glucagon, somatostatin and pancreatic polypeptide cells seemed unaffected (Fig. 3). These observations support the view that the insulin cells are important target cells for tolbutamide and further suggest that a reduced quinacrine fluorescence intensity reflects an increased insulin granule turn-over [2, 20].

It has been shown previously that administration of the quinacrine-analogue chloroquine affects the secretory activity of insulin cells. Thus long-term experiments in vitro with cultured islets showed that this drug inhibited insulin secretion and synthesis, whereas a slight stimulatory effect on release was noted in acute experiments [15]. Pretreatment $(20 \mathrm{~h})$ of mice with quinacrine in the present study slightly enhanced basal insulin secretion without changing the plasma glucose level. Further, quinacrine pretreatment greatly increased the insulin secretory response to glucose without affecting the insulin response to cholinergic stimulation. This differential effect on stimulated insulin release is highly suggestive of important differences in the stimulus-secretion coupling for these secretory pathways. Since quinacrine accumulates in the secretory granules (and possibly lysosomes) there is reason to believe that the effect of quinacrine on glucose-induced insulin release may be exerted within the secretory granules and/or lysosomes. The mechanism of action of quinacrine is not 
known. In addition to the well-known binding to DNA [21] the quinacrine analogue chloroquine produces a variety of effects, many of which have been related to accumulation in lysosomes. Changes that have been described include: inhibition of catheptic activity and degradation of proteins [22], lysosomal labilization [23], and enhancement of lysosomal fusion with other organelles [24]. Whether such effects are relevant for the effect of quinacrine on glucose-induced insulin release must await further study. However, it should be pointed out that the present results appear compatible with the hypothesis [25] that glucose-induced insulin release may involve lysosomal activation. Furthermore, previous investigations have shown that the insulin secretory response induced by glucose, but not that induced by cholinergic stimulation, was related to the activity of the lysosomal enzyme acid amyloglucosidase in the pancreatic islets [25-27].

In conclusion, the acridine derivative quinacrine accumulates in the insulin, glucagon, pancreatic polypeptide and somatostatin cells of the pancreatic islets in the rat and mouse. Degranulation of the insulin cells by the sulphonylurea drug tolbutamide substantially reduces the ability of these cells to accumulate quinacrine, suggesting that the drug is associated with the secretory granules. Quinacrine pretreatment greatly enhanced the glucose-induced insulin release in mice without affecting the insulin release induced by cholinergic stimulation, suggesting different secretory pathways for these two secretagogues.

Acknowledgements. The authors express their appreciation to L. Kvist and P.Okmark for technical assistance and to E. Björkbom for secretarial help. This study was supported by the Swedish Medical Research Council (14P-4289, 14X-4286, 14P-6647, 14X-6837 and 04X1007), the Swedish Diabetes Association, and the Medical Faculty, University of Lund, Lund, Sweden.

\section{References}

1. Ålund M, Olson L (1979) Quinacrine affinity of endocrine cell systems containing dense core vesicles as visualized by fluorescence microscopy. Cell Tiss Res 204: 171-186

2. Ekelund M, Ahrén B, Hâkanson R, Lundquist I, Sundler F (1980) Quinacrine accumulates in certain peptide hormone-producing cells. Histochemistry $66: 1-9$

3. Jennings BM (1965) Aldehyde-fuchsin staining applied to frozen sections for demonstrating pituitary and pancreatic beta-cells. J Histochem Cytochem 13: 328-333

4. Lundquist I, Håkanson R, Harris JB, Libelius R, Sundler F (1979) Endocrine pancreas in the dystrophic mouse. Ann NY Acad Sci 317:206-220

5. Larsson L-I, Holst J, Håkanson R, Sundler F (1975) Distribution and properties of glucagon immunoreactivity in the digestive tract of various mammals: an immunohistochemical and immunochemical study. Histochemistry 44: 281-290

6. Larsson L-I, Sundler F, Håkanson R (1976) Pancreatic polypeptide - a postulated new hormone: identification of its cellular storage site by light and electron microscopic immunocytochemistry. Diabetologia 12: $211-226$

7. Alumets J, Sundler F, Håkanson R (1977) Distribution, ontogeny and ultrastructure of somatostatin immunoreactive cells in the pancreas and gut. Cell Tissue Res 185: 465-479
8. Björklund A, Falck B, Owman Ch (1972) Fluorescence microscopic and microspectrofluorometric techniques for the cellular localization and characterization of biogenic amines. In: Berson SA (ed) Methods of investigative and diagnostic endocrinology, Vol 1. Rall JE, Kopin IJ (eds) The thyroid and biogenic amines. NorthHolland Publication Company, Amsterdam, pp 318-368

9. Rerup C, Lundquist I (1966) Blood glucose level in mice I. Evaluation of a new technique of multiple serial sampling. Acta Endocrinol (Copenh) 52: 357-367

10. Ahrén B, Lundquist I (1981) Effects of selective and non-selective $\beta$-adrenergic agents on insulin secretion in vivo. Eur J Pharmacol $71: 93-104$

11. Lundquist I (1972) Acid amyloglucosidase and carbohydrate regulation. I. Effect of exogenous amyloglucosidase on tissue glycogen, blood glucose and plasma insulin. Horm Metab Res 4: 151-158

12. Heding $L$ (1966) A simplified insulin radioimmunoassay method. In: Donato L, Milhaud G, Sirchis J (eds) Labelled proteins in tracer studies. Euratom, Brussels, pp 345-350

13. Bruss ML, Black AL (1978) Enzymatic microdetermination of glycogen. Anal Biochem 84: 309-312

14. Dencker L, Lindquist NG, Tjälve $H$ (1976) Uptake of ${ }^{14}$ C-labelled chloroquine and an ${ }^{125} \mathrm{I}$-labelled chloroquine analogue in some polypeptide hormone producing cell systems. Med Biol 54: 62-68

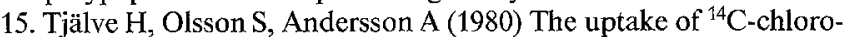
quine by mouse pancreatic islets in vitro. Acta $P$ harmacol Toxicol (Copenh) 47: 38-44

16. Andersson A, Olsson S, Tjälve H (1980) Chloroquine inhibits the insulin production of isolated pancreatic islets. Biochem Pharmacol 29: 1729-1735

17. Winkler $H$ (1977) The biogenesis of adrenal chromaffin granules. Neuroscience 2: 657-683

18. Hutton JC (1982) The internal $\mathrm{pH}$ and membrane potential of the insulin-secretory granule. Biochem J 204: 171-178

19. DeDuve C, deBarsy T, Poole B, Trouet A, Tulkens P, van Hoof F (1974) Lysosomotropic agents. Biochem Pharmacol 23: 2495-2531

20. Ålund M (1980) Juxtaglomerular cell activity during hemorrhage and ischemia as revealed by quinacrine histofluorescence. Acta Physiol Scand 110: 113-121

21. Rollo IM (1980) Drugs used in the chemotherapy of malaria. In: Gilman AG, Goodman LS, Gilman A (eds) The pharmacological basis of therapeutics. MacMillan, New York, pp 1038-1060

22. Wibo M, Poole B (1974) Protein degradation in cultured cells. II. The uptake of chloroquine by rat fibroblasts and the inhibition of cellular protein degradation and cathepsin $\mathrm{B}_{1}$. J Cell Biol 63: $430-440$

23. Filkins JP (1969) Effect of chloroquine on hepatic lysosomes. Fed Proc 28: 266 (Abstract)

24. Hart PD'A, Young MR (1979) The effects of inhibitors and enhancers of phagosome-lysosome fusion in cultured macrophages on the phagosome membranes of ingested yeasts. Exp Cell Res 118: 365-375

25. Lundquist I (1975) Carbohydrate content and regulation following injection of different glycogenolytic enzymes. Enzyme 20: 234-247

26. Lundquist I, Lövdahl R (1977) Pattern of islet lysosomal enzyme activities and insulin secretory response. Enzyme 22: 385-390

27. Lundquist I (1982) Cholinergic muscarinic effects on insulin release in mice. Pharmacology $25: 338-347$

Received: 8 May 1984

and in revised form: 18 December 1984

Dr. I.Lundquist

Department of Pharmacology

Sölvegatan 10

S-223 62 Lund

Sweden 